\title{
THE POTENTIAL IMPLEMENTATION OF STORMWATER RETENTION PONDS INTO THE BLUE-GREEN INFRASTRUCTURE OF THE SUBURBAN LANDSCAPE OF PILSEN, CZECHIA
}

\author{
KOPP, J. ${ }^{*}$ - PREIS, J. \\ Department of Geography, Faculty of Economics, University of West Bohemia \\ Univerzitní 22, 30614 Pilsen, Czechia \\ (phone: +420-377-631-111; fax: +420-377-631-112) \\ ${ }^{*}$ Corresponding author \\ e-mail: kopp@kge.zcu.cz; phone: +420-377-633-065 \\ (Received 25 $5^{\text {th }}$ Jun 2019; accepted $25^{\text {th }}$ Oct 2019)
}

\begin{abstract}
This study investigates the requirements for creating blue-green infrastructure (BGI) as an instrument of stormwater management, in which nature-based solutions in urban and suburban landscapes are preferred. This case study of stormwater retention ponds (SWRPs) in the suburban landscape surrounding the city of Pilsen (Czechia) evaluates selected qualitative parametres of SRWPs on private land. Evaluated SWRPs have been classified according to the ownership relations and the potential indicators of their involvement within the BGI. Although the drain control as a primary purpose of SRWPs is a main criterion of their design, the ponds' parameters may differ from each other based on how their nature-based elements are used as well as what their amenity functions in a public space are. Based on the analyses of SRWPs' potential, the case study recommends public administration to provide some tools to support the private sector. The economic tools, motivating private sector, must be enhanced. An example of such an instrument could be the establishment of fees for stormwater drainage taking the ecosystem quality of the water management solutions into account.
\end{abstract}

Keywords: ecosystem services, hydro-social system, nature-based solutions, private land, rainwater management, landscape planning

\section{Introduction}

Water management in urban agglomerations has been transforming significantly and systematically in the 21st century: it is characterised by its decentralization (Schmidt, 2009; Rygaard et al., 2011; Elemer and Fraker, 2012; Wong, 2013; Yang et al., 2019). Cities all over the world endeavor to react to climate changes, especially to unbalanced rainfall regime and the increasingly frequent deepening occurrence of temperature extremes. These issues are mainly caused by the relatively high number of artificial and watertight surfaces in both urban and suburban landscapes. In spite of the fact that the hydrological cycle's changes are most obvious in urban landscape, it is necessary to remember a sustainable planning of suburban landscape too (Antrop and Entvelde, 2000). Such a landscape has specific ecological characteristics: It is characterized by a connectivity matrix and a high level of landscape heterogeneity. It means that large number of land covers is present (Antrop and Entvelde, 2000). The areas of the suburban landscape are used with different intensity - on the one hand, there are places strongly transformed by humans, such as industrial or commercial grounds (Spilková and Šefrna, 2010). On the other hand, there are nature-based surfaces, such as residual wetlands (Ehrenfeld, 2000). Historical development of catchment area situated next to urban 
agglomeration generally enhances the proportion of watertight surfaces and thus changes the hydrological regime (Koronkevich and Mel'nik, 2015).

The functions of a suburban landscape, connected to land use categories could be divided into three groups: i) urban functions (residential housing, transport communication, commercial centres, industrial zones); ii) production functions (agricultural and forestry); iii) specific suburban functions (recreational water areas; parks; background of urban infrastructure, such as waterworks or sewerage; dump; mining areas). Changes of water drainage are influenced especially by a significant increase of built up areas as a direct consequence of residential and commercial suburbanization (Miller and Hess, 2017). That's why it is necessary to pay attention to developing blue-green infrastructure (BGI) in localities of suburban landscape. BGI via nature-close remedies should help to mitigate fast water drainage, increase evapotranspiration and replenish groundwater reserves.

The term "blue-green infrastructure" is used rarely in the Czech environment and when the term is used is mostly referring to foreign sources via inaccurate references. From the terminological point of view, there is a discussion about "green infrastructure" in the Czech Republic, which is based on the European Commission's inputs (EC, 2013; Kopp et al., 2017). Czech planning practice has had quite a solid experience with "ecological networking", in Czech terminology known as "Territorial systems of ecological stability" (ÚKRMP, 2016). Unlike foreign countries, where planning of functionally interlinked infrastructure is often considered in expert studies and plans (e.g. Wagner et al., 2013; Faltermaier et al., 2016; Bozovic et al., 2017), in the Czech Republic, there are only plans to broaden ecological networks from undeveloped landscape to the urban landscape. Thus, for our research purposes, we come from of the conceptions of blue-green infrastructure according to foreign studies (Voskamp and Van de Ven, 2015; van Timmeren et al., 2015; DELWP, 2017).

The authors of this paper understand blue-green infrastructure (BGI) primarily as an instrument for stormwater management, in which ecosystem approaches and water management measures are interlinked with green networks' system (Wagner et al., 2013; Voskamp and Van de Ven, 2015; DELWP, 2017). In this sense, the primarily urban concept of BGI (van Timmeren et al., 2015; Bacchin et al., 2016) builds on the more universal concept of green infrastructure, as it is defined by the European Commission (EC, 2013). Implementation of BGI is significant from the water management's perspective, which could be summarized into three main goals (Faltermaier et al., 2016; Bozovic et al., 2017; DELWP, 2017): (1) to retain rainwater and use it efficiently on places where it falls, (2) to reduce the accelerated runoff from surface into integrated sewerage system and via its overflows into watercourses, (3) to help water bodies, wetlands and verdure to evaporate and thus to decrease the effect of overheated urban and suburban areas.

\section{The objective of the study}

In the case study of the Pilsen suburban landscape, we deal with stormwater retention ponds (SRWPs) which have been implemented into individual areas as retention elements for rainwater. The water retained in them is not used in the next operational cycle. The objective of this case study is to assess selective qualitative parameters of selected SRWPs and to evaluate their potential to be engaged into the BGI of the suburban landscape. In a subsequent discussion of the results, we bring recommendations for regional and local administration, how to engage a private sector into a sustainable management of the 
suburban landscape. To be more concrete, our goal is to propose instruments that can motivate the private sector to pay attention to SRWPs not only because of their retention function, but also to support their ecosystem services as well.

\section{Review of literature}

\section{Hydro-social context of the BGI implementation}

The implementation of BGI could be generally understood as a part of systematic changes in water management of the cities: i) a level of new technology's application (e.g. green roofs, water recycling); ii) a level of organization (e.g. building of decentralized water management zones; integration of the water issue in urban and landscape planning) and iii) a level of thinking (Bozovic et al., 2017). From the sustainable development point of view, the BGI benefits are not primarily related just to water management, but have also ecosystem and social aspects (van Timmeren et al., 2015). The BGI tools are targeted to four key issues (Woods Ballard et al., 2015):

1) Quantity of water: to decrease flood risk; to support and protect the hydrologic cycle;

2) Quality of water: to eliminate sources of pollution of water drainage;

3) Amenities: to create better and more sustainable environment for the life of humans;

4) Biodiversity: to create better and more sustainable environment for organisms.

For example, a British concept Blue-Green City is based on requests for flood protection and simultaneously for quality of life in cities with utilization of ecosystem measures. It pays attention to participatory planning process and evaluation of costs and benefits of blue-green infrastructure elements' implementation (Hoang and Fenner, 2015).

To search BGI tools properly, it is necessary to expand the view on the hydrological system. We have to look at it not only from physical and biochemical perspectives but add to them also a level of hydro-social system, in which human activities have a fundamental link to individual parts of water circulation in landscape (Swyngedouw, 2009; Linton and Budds, 2014). To improve BGI management, it is important to study relations between a regional administration and a private sector that could be both potential barriers and opportunities in water management. There are generally three categories of instruments which a regional administration can use to influence the implementation of new sustainable technologies in private sectors (Retzlaff, 2008; Carter and Fowler, 2008; Ferguson et al., 2013; Kabisch et al., 2016):

a) normative instruments (regulatory): e.g. adaptation strategies, urban and landscape plans, regulatory plans, building regulations, city ordinances, territorial protection, water directives, standards, norms,

b) economic instruments (financial): European/national/municipal subsidies, charging of rainwater discharge, tax allowance to properties with eco-labeling, grant schemes, bonuses in the form of favorable construction conditions,

c) ethical instruments (informational and motivational): programs focused on environmental education, awareness raising campaigns, professional training, environmental marketing of cities or developer projects, good practice examples, participatory planning, eco-labeling of companies, services and buildings.

Ethical instruments have also a significant potential. They can be linked with economic advantages if companies acquire eco-certificate for their operations. Regional administration can provide eco-labeling for companies, which carry out nature-based 
solutions beyond compulsory water management measures and thus motivate private sector to enhance their own prestige. In the case of apartment construction, developers use eco-parametres of new residential zones as an instrument for their environmental marketing. Potential of hobby stores as possible epicentres of nature-based promotion of water management on a private land is not used. Despite the fact that they offer their clients artificial ponds for rainwater retention, semi-permeable tiles or a material to build green roofs or green facades, the buildings of these hobby stores unfortunately do not demonstrate any of those solutions.

A more sophisticated level of collaboration between a regional administration and a private sector are partnership projects. The foreign examples show that it is possible to mutually cultivate environmental quality of a territory, if a marketing and conditions for participation are set well. There are several projects that could be examples of joint venture, such as Oeko Business Wien, GreenMoabit Berlin (Pizarro, 2015).

The important instrument to support BGI implementation into practice is PublicPrivate-Partnership (PPP) (WEF, 2014; Harman et al., 2015; McAllister and Taylor, 2015; Margerum and Robinson, 2015; Koppenjan, 2015). PPP could be drawn up as build-operate-and-transfer (BOTs) arrangements, build-operate-own-transfer (BOOT), design-build-operate (DBO), joint-ventures or voluntary agreements (Hayllar, 2010; Harman et al., 2015). With regard to climate changes, BGI building belongs to PPP projects that are beneficial in terms of both adaptation and mitigation.

\section{Stormwater retention ponds (SWRPs) as a part of BGI}

Due to the fact that different instruments are recommended for different areas (e.g. industrial areas, shopping areas, or residential areas), it is necessary to adapt BGI planning in the suburban landscape with regard to land use (Faltermaier et al., 2016). It is appropriate to interconnect suitable elements of BGI with individual types of the landscape in relation to the systems of ecological stability of agricultural areas (Krauze and Wagner, 2019). Stormwater retention ponds (SWRPs) as a frequently used rainwater management instrument is applied in industrial, commercial and residential zones as well as in relation to drainage of roads. (Wong et al., 1998; Scher et al., 2004; USEPA, 2009; Faltermaier et al., 2016).

In spite of the fact that SWRPs are constructed as water management elements, we can sort them to BGI elements too (Hoang and Fenner, 2015). SWRPs, together with wetlands, are classified in methodological manuals about BGI implementation as surface retention elements that are able to clean water and are highly beneficial to the biodiversity of the landscape (Woods Ballard et al., 2015). SWRPs excel in high retention efficiency depending on the retention pond volume. At the same time, both SWRPs and wetlands have the highest initial costs (Hoang and Fenner, 2015). Due to the fact that the hydrological retention function of SWRPs is the top priority, it is also necessary to pay attention to their ecosystem and amenity potentials (Kurilenko and Osmolovskaya, 2007; Chiandet and Xenopoulos, 2011; Noble and Hassall, 2015; Hill et al., 2017).

It is important to deal with a question how to enhance the ecosystem and amenity benefits of SWRPs and how to implement them fully into the BGI of suburban landscape (Moore and Hunt, 2012). Their nature-based qualities determine whether they become a valuable part of the BGI or if they will remain just technical components of a grey infrastructure (Moore and Hunt, 2012; Hoang and Fenner, 2015). There are various types of urban ponds in BGI of urban and suburban landscape. SRWPs, which this paper deals with, are classified as Drainage systems ponds (Hassall, 2014). They differ primarily from 
other categories, such as Garden ponds or Ornamental lakes and ponds by their retention function and possibly cleaning effect of contaminated water. Industrial ponds differ from them by an engagement into water management operation of the enterprise. Drainage system ponds can be classified as "detention" or "retention" ponds (Hill et al., 2017). With regard to a potential ecosystem benefit, retention ponds (SRWPs) are more important. A stable amount of retained water creates an aquatic environment and a design of a bench zone enables littoral vegetation to occur (USEPA, 2009).

\section{Materials and methods}

\section{Study area and study sites}

The Pilsen city's suburban landscape is currently an area with clearly obvious features of suburbanization, because of the population size of the Pilsen city (170.000 inhabitants in 2018) and its dominant position in the settlement system of the western part of the Czech Republic (Kopp et al., 2015). A significant share of a suburban landscape is located in the frame of the administrative region of the city. Out of $138 \mathrm{~km}^{2}, 27.2 \%$ is arable land, $7.2 \%$ is grassland and $20.6 \%$ is forest area (Kopp et al., 2017). The area of production and storage is also a significant feature of urban and suburban landscapes, with a share of $7.2 \%$ of the total extent of the administrative region and $17.2 \%$ of the built-up area in the urban and suburban landscape. An important category of land use is also shop and service area that makes $1.7 \%$ of the total extent of the region and $4.1 \%$ of the built up area (Kopp et al., 2017). New studies point out that those production and storage areas as well as shopping and service zones contribute significantly to making heat islands in the area of the Pilsen agglomeration. Building of those kinds of zones as a part of a commercial suburbanization process at the turn of the century brought extension to typically urban problems of hydrological balance in suburban landscape. Studies from other areas point to similar problems as well (Le Viol et al., 2009; Chiandet and Xenopoulos, 2011; Cizek and Hunt, 2013).

Average annual rainfall in 2006-2015 recorded at the Pilsen-Mikulka station was $514.8 \mathrm{~mm}$. If a cadastral area of the city of Pilsen is $137.67 \mathrm{~km}^{2}$, the total average annual amount of rainwater falling on the city is 74.6 mil. $\mathrm{m}^{3}$ (Kopp et al., 2017).

According to the standardized values of the Czech Hydrometeorological Institute for the period 2005-2015 for the station Pilsen-Mikulka, a thirty minute rain with a periodicity of repetition $n=1$ year causes a direct specific runoff of 115.6 litres per second per hectare $\left(115.61 . \mathrm{s}^{-1} \cdot \mathrm{ha}^{-2}\right)$. A result of such an extreme rainfall event is overloading of the sewerage network and contaminated water overflowing via a drain directly into local watercourses. For example, two consecutive events 5th July 2018 (22 mm) and 6th July $2018(10 \mathrm{~mm})$ caused disposable pollution of the river. Due to an oxygen deficit, about 3-5 metric tonnes of fish died (Povodí Vltavy, 2018). That's why it is important to enhance a retention ability of both urban and suburban landscapes connected to sewerage.

The private sector in the city of Pilsen has been obliged, according to state law and city regulation, to deal with rainwater drainage from impervious surfaces (roofs, parking sites or roads) in the last decade. They have been responsible to limit drainage into the sewerage system below $41 . \mathrm{s}^{-1} \cdot \mathrm{ha}^{-2}$. Subsurface or surface retention ponds (SWRPs) are allowed if is impossible for rainwater to infiltrate or to use it in another way inside the area of the enterprise (Vítek et al., 2015).

Dozens of SRWPs of different design have been built in the suburban landscape, most of them are located on private land. Our paper focuses on and evaluates five SRWPs in 
detail (PP1-PP5, Fig. 1, Table 1), which are located on private land. Their parameters are compared with two other SWRPs (PM1-PM2, Fig. 1, Table 1), that were designed for the purpose of private construction, but were handed over to the city administration, whose lands they are located on. They were built to runoff rainwater from the zones of the developer construction projects and their property relations could be classified as "combined" (Freie und Hansestadt Hamburg, 2013). Due to the fact that we compare an ecosystem potential of ponds, we included also one retention pond that the city designed and built as a demonstration project to support BGI during reconstruction of a historic park (MM1, Fig. 1, Table 1).
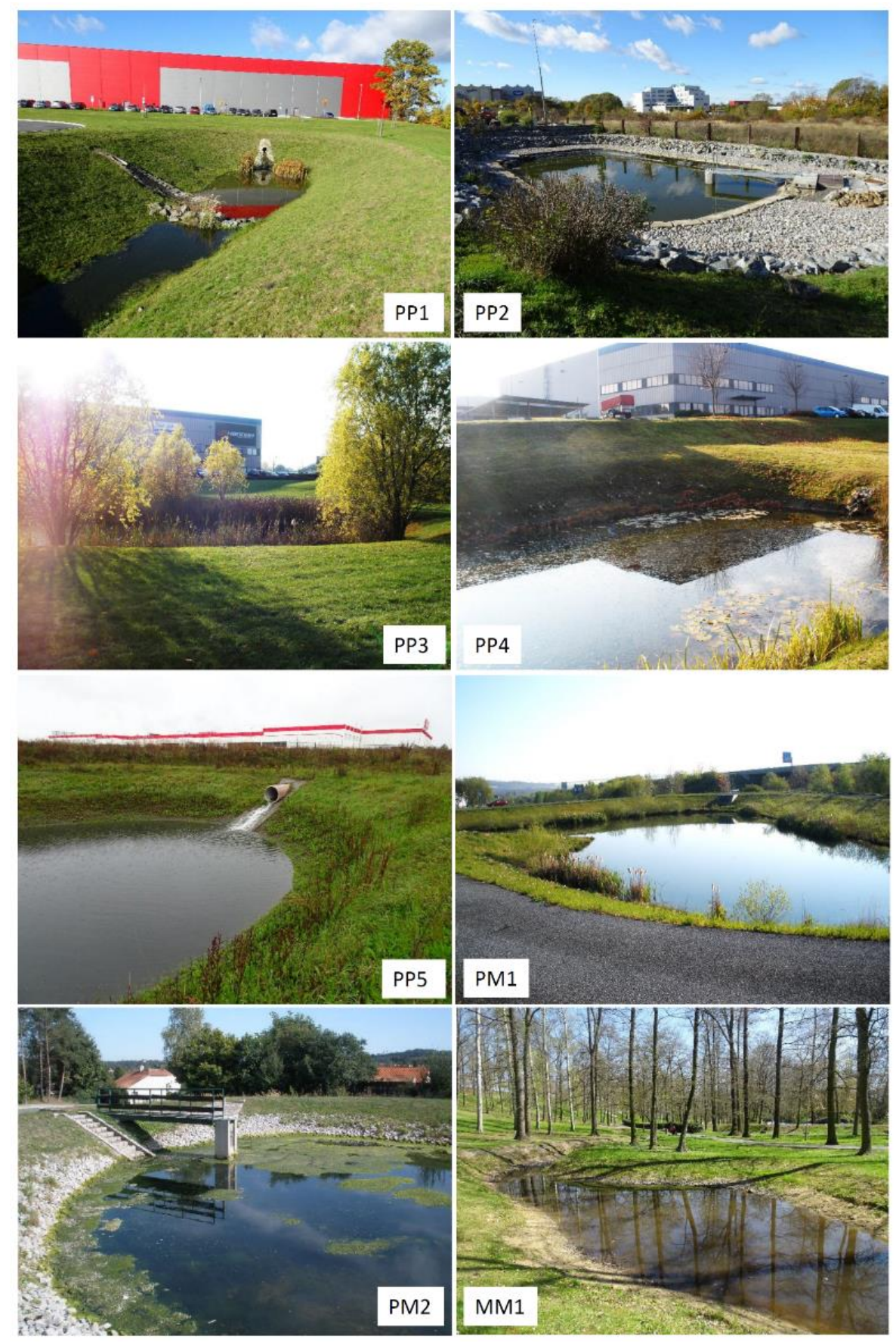

Figure 1. Different design of surface retention ponds in a case study 
Kopp - Preis: The potential implementation of stormwater retention ponds into the blue-green infrastructure of the suburban landscape of Pilsen, Czechia

$$
-15061-
$$

Table 1. Location and property relations of surface retention ponds in a case study

\begin{tabular}{|c|c|c|c|c|c|}
\hline $\begin{array}{l}\text { Type by property } \\
\text { relations of the } \\
\text { retention pond's } \\
\text { drainage area }\end{array}$ & $\begin{array}{l}\text { Retention ponds } \\
\text { (suburban unit) } \\
\text { coordinates WGS84 }\end{array}$ & $\begin{array}{l}\text { Land use of the } \\
\text { retention pond's } \\
\text { drainage area }\end{array}$ & $\begin{array}{c}\text { Type of } \\
\text { investment }\end{array}$ & \begin{tabular}{|} 
Property \\
relations of the \\
retention \\
pond's land
\end{tabular} & $\begin{array}{l}\text { Management of } \\
\text { the retention } \\
\text { pond }\end{array}$ \\
\hline \multirow{5}{*}{ private $(\mathrm{PP})$} & $\begin{array}{c}\text { PP1 (Černice 1) } \\
49^{\circ} 42^{\prime} 27^{\prime \prime N}, 13^{\circ} 25^{\prime} 50^{\prime \prime E}\end{array}$ & light industry & private & private & private \\
\hline & $\begin{array}{c}\text { PP2 (Černice 2) } \\
49^{\circ} 42^{\prime} 15^{\prime \prime} \mathrm{N}, 13^{\circ} 25^{\prime} 56^{\prime \prime} \mathrm{E}\end{array}$ & light industry & private & private & private \\
\hline & $\begin{array}{c}\text { PP3 (Křimice 1) } \\
49^{\circ} 45^{\prime} 03^{\prime \prime N}, 13^{\circ} 19^{\prime} 29^{\prime \prime E} \\
\end{array}$ & light industry & private & private & private \\
\hline & $\begin{array}{c}\text { PP4 (Křimice 2) } \\
49^{\circ} 45^{\prime} 01^{\prime \prime N}, 13^{\circ} 19^{\prime} 37^{\prime \prime E}\end{array}$ & light industry & private & private & private \\
\hline & $\begin{array}{c}\text { PP5 (Borská pole) } \\
\text { 4943'39"N, 13²1'09"E }\end{array}$ & shopping center & private & private & private \\
\hline \multirow{2}{*}{$\begin{array}{c}\text { private/ } \\
\text { municipal (PM) }\end{array}$} & $\begin{array}{c}\text { PM1 (Černice } 3) \\
49^{\circ} 41^{\prime} 52^{\prime \prime} \mathrm{N}, 13^{\circ} 25^{\prime} 46^{\prime \prime} \mathrm{E} \\
\end{array}$ & mixed & private & municipal & municipal \\
\hline & $\begin{array}{c}\text { PM2 (Nová Valcha) } \\
49^{\circ} 42^{\prime} 34^{\prime \prime N}, 13^{\circ} 19^{\prime} 34^{\prime E} \\
\end{array}$ & residential housing & private & municipal & municipal \\
\hline municipal (MM) & $\begin{array}{c}\text { MM1 (Lochotín) } \\
49^{\circ} 45^{\prime} 37^{\prime \prime N}, 13^{\circ} 21^{\prime} 56^{\prime \prime E}\end{array}$ & park & municipal & municipal & municipal \\
\hline
\end{tabular}

\section{Methodology of evaluation of SRWPs'potential}

Neither city nor state administrations have systematically recorded SRWPs, which are of interest to this case study. If it is possible to see construction documents (private subjects provide these documents for the research purposes only limited), it is possible to find out technical parameters of the ponds and their planned hydrological functions. When SRWPs are projected and built, the attention toward ecosystem and amenity functions is marginal. No monitoring of their hydrological regime, chemical and hydrobiological status is required, thus it does not exist at all. Some ponds are not accessible due to private property's protection or due to security reasons. The evaluation of SWRPs was primarily based on assessing their spatial parametres using orthophoto maps from different seasons between 2014-2017. We tried to find such pictures, where different levels of replenishment of the pond (and thus different aquatic zone areas) were captured $\left(\mathrm{A}_{\text {std }}, \mathrm{A}_{\mathrm{min}}\right)$. Another parameter is the detected area of the ponds including safety bench area (USEPA, 2009), which is usually an area of unflooded safety volume $\left(\mathrm{A}_{\max }\right)$. All areas are calculated using orthogonal projection, which was obtained by ortophoto map analysis via geographical information system ArcGIS. The perimeter of a pond is related to a standard area in time, when a pond is normally filled. Out of those parametres, indexes have been calculated:

a) Area amplitude index:

$$
I_{a}=\frac{A_{s t d}}{A_{\min }}
$$

b) Area unflooded benches index:

$$
I_{b}=\frac{A_{\max }-A_{\text {std }}}{A_{\text {std }}}
$$


c) Shape index - ratio of the perimeter area $\left(\mathrm{P}_{\text {std }}\right)$ to the perimeter of a circle with the same area $\left(\mathrm{A}_{\text {std }}\right)$ :

$$
I_{c}=\frac{P_{s t d}}{2 \sqrt{\pi} \times \sqrt{A_{s t d}}}
$$

These indexes enable us to compare geometrical parameters of the ponds in regard to their ecosystem potential. The ponds with irregular shape with more segmented bench line (Eq.3) have a similar quality as natural ponds and have also a potential for higher biodiversity (NJDEP, 2006; Moore and Hunt, 2012). These ponds have also a higher potential of ecological stability in case lower fluctuation of the pond level and area amplitude (Eq.1, Eq.2). These features depend on bank's inclination and a set mode of inflow and outflow (Wong et al., 1998; NJDEP, 2006; Blicharska et al., 2016).

Next evaluation of SRWPs has been done according to six criteria that come from recommended features and qualities of ponds included into BGI (Wong et al., 1998; Blicharska et al., 2016). The potential of connection into the BGI network is characterised by a positional feature, which provides a possible link to close elements of green network and water bio-corridors. Ecosystem potential has been distinguished according to the existence and ecological quality of the bench vegetation. A microclimatic significance of ponds has been classified based on a contrast with surrounding areas located nearby, while taking into account the area size. Next two criteria - aesthetic quality and its implementation into a public space - express a social importance of SWRPs as elements of the BGI in a suburban landscape. It is important to distinguish whether a water body is or is not publicly accessible (Li et al., 2019). Even if it is located on a private property, it could be made publicly accessible, as it is obvious in agricultural landscape. The evaluation according to selected criteria has been made via field research and assessment of orthophoto pictures (Fig. 2) and documents for city planning. A score for each criterion was made in a scale from 0 to 3 ( 3 equals the best quality). Rating scales have been derived from particular studies and manuals focusing on the construction of retention ponds according to monitored criteria (Wong et al., 1998; NJDEP, 2006; USEPA, 2009; Moore and Hunt, 2012; Blicharska et al., 2016; Teurlincx et al., 2019) with a request to set the same scale for all parameters. The evaluation of SWRPs was made based on our own assessment in the field. Particular maps and the Master plans' documentation have been used to evaluate certain criteria (potential of connection into the BGI network; microclimatic significance) (ÚKRMP, 2016). Weight for each criterion was not considered, so it was decided that total score equals from $60 \%$ ecosystem quality and $40 \%$ social quality of SWRPs. Nevertheless, both quality aspects correlate together, for example with an assessment of bank quality or an aesthetic value.

Due to the fact that it was impossible to compare a hydrological regime of ponds using the above-mentioned methodological procedure, our own hydrological monitoring of the water levels in the ponds was used as a material for a follow-up discussion of SWRPs potential. The water level has been realized since mid-2017 on the tank PM2 located in the Nova Valcha site. A primary purpose of this pond is to a course of a runoff from new residential zone's rainwater sewerage. The secondary purpose according to a project documentation is to be a landscaping element in a transitional zone between new buildings and old buildings of the Valcha urban area. 

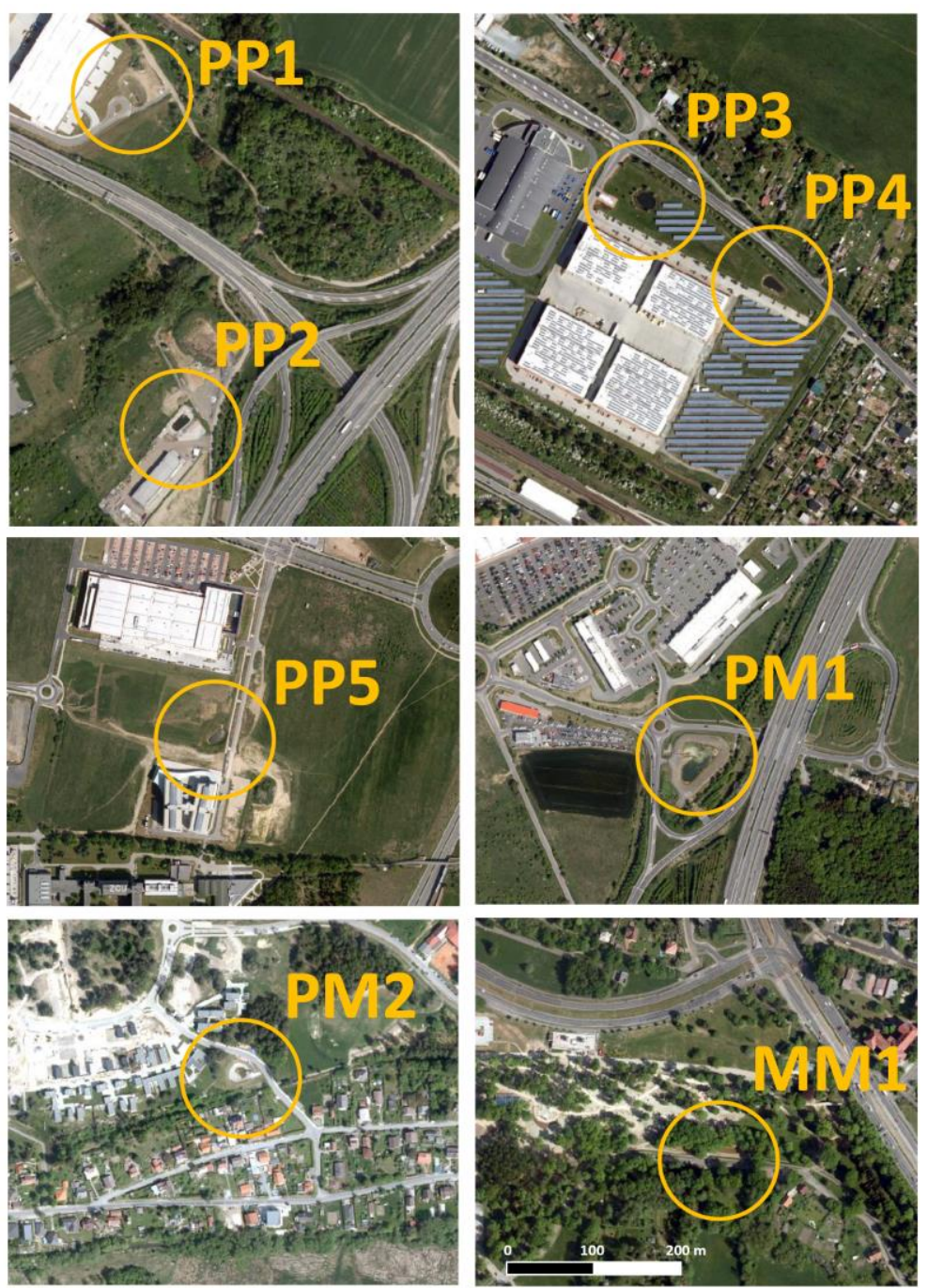

Figure 2. Location of surface retention ponds in suburban landscape (orthophoto Czech Office for Surveying, Mapping and Cadastre)

\section{Results}

A comparison of area parametres of SWRPs monitored in the suburban landscape proved their different preconditions to be implemented into BGI (Table 2, Table 3). Their cubic capacity differs depending on the drainage area. Thus, their sizes differ as well, which directly influences their microclimatic potential. The whole expanse of the tank directly influences the PM1 retention, which drain to a broader zone of a new construction area including impermeable surfaces of surrounding communications (Table 2).

A pipeline capacity bringing rainwater corresponds with area and volume of a pond. The pond PP1 has a significant area of unflooded bench slopes, which is in compliance with morphometry and a safety water level of a maximum volume. Consequently, the water level is thus cut deeply under a level of a terrain, which complicates a link of the pond's ecosystem with surrounding areas. From a broader point of view, it also decreases its impact on an aesthetic composition of the landscape. From an aesthetic point of view (Table 3), positively influencing aspects are considered not only a quality of vegetation on the benches (PP3) and a morphometry of the bench (MM1), but also adjustment of 
them. These modifications, however, do not have an ecosystem function's potential (PP2). The essential aspects of ecosystem quality (Table 3) are predominantly a segmentation of the pond's shape (MM1) and a quality ecosystem of a bank with its woody plants (PP3). Littoral vegetation is scarce at SRWPs, due to a morphometry of ponds, that are primarily focused on a retention volume. In this way, a potential of SRWP is much lower in comparison with constructed wetlands.

Table 2. Parametres of surface retention ponds

\begin{tabular}{c|c|c|c|c|c|c|c}
\hline $\begin{array}{c}\text { Retention } \\
\text { pond }\end{array}$ & $\begin{array}{c}\mathbf{A}_{\min } \\
\left(\mathbf{m}^{\mathbf{2}}\right)\end{array}$ & $\begin{array}{c}\mathbf{A}_{\text {std }} \\
\left(\mathbf{m}^{\mathbf{2}}\right)\end{array}$ & $\begin{array}{c}\mathbf{A}_{\mathbf{m a x}} \\
\left(\mathbf{m}^{\mathbf{2}}\right)\end{array}$ & $\begin{array}{c}\mathbf{P}_{\text {std }} \\
(\mathbf{m})\end{array}$ & $\begin{array}{c}\mathbf{I}_{\mathbf{a}}-\text { Area } \\
\text { amplitude index }\end{array}$ & $\begin{array}{c}\mathbf{I}_{\mathbf{b}}-\text { Area } \\
\text { unflooded banks } \\
\text { index }\end{array}$ & $\mathbf{I}_{\mathbf{c}}-$ Shape index \\
\hline PP1 & 120 & 125 & 758 & 57 & 1.04 & 5.06 & 1.44 \\
PP2 & 223 & 228 & 500 & 59 & 1.02 & 1.19 & 1.10 \\
PP3 & 460 & 465 & 664 & 79 & 1.01 & 0.43 & 1.03 \\
PP4 & 283 & 291 & 364 & 68 & 1.03 & 0.25 & 1.12 \\
PP5 & 363 & 492 & 910 & 84 & 1.36 & 0.85 & 1.07 \\
PM1 & 1677 & 1710 & 3145 & 187 & 1.02 & 0.84 & 1.28 \\
PM2 & 145 & 363 & 658 & 69 & 2.50 & 0.81 & 1.02 \\
MM1 & 255 & 290 & 529 & 169 & 1.14 & 0.82 & 2.80 \\
\hline
\end{tabular}

Table 3. Score of the retention ponds quality

\begin{tabular}{c|c|c|c|c|c|c}
\hline $\begin{array}{c}\text { Retention } \\
\text { pond }\end{array}$ & $\begin{array}{c}\text { Potential of } \\
\text { connection into } \\
\text { the BGI } \\
\text { network }\end{array}$ & $\begin{array}{c}\text { Ecological } \\
\text { quality of the } \\
\text { bank's } \\
\text { vegetation }\end{array}$ & $\begin{array}{c}\text { Microclimatic } \\
\text { significance } \\
\text { contrast and } \\
\text { area) }\end{array}$ & $\begin{array}{c}\text { Aesthetic } \\
\text { quality }\end{array}$ & $\begin{array}{c}\text { Accessibility and } \\
\text { implementation into } \\
\text { a public space }\end{array}$ & $\begin{array}{c}\text { Total } \\
\text { score of } \\
\text { quality }\end{array}$ \\
\hline PP1 & 1 & 1 & 1 & 2 & 1 & 6 \\
PP2 & 0 & 0 & 2 & 3 & 0 & 5 \\
PP3 & 2 & 3 & 2 & 3 & 0 & 10 \\
PP4 & 1 & 2 & 2 & 2 & 0 & 6 \\
PP5 & 1 & 1 & 3 & 1 & 0 & 5 \\
PM1 & 1 & 2 & 2 & 1 & 2 & 7 \\
PM2 & 1 & 0 & 1 & 3 & 3 & 6 \\
MM1 & 3 & 2 & 2 & 0 & 12 \\
\hline
\end{tabular}

Note: Score for each criterion in a scale from 0 to 3 (3 equals the best quality)

The implementation of SRWPs into BGI results in their position and various conditions of the surrounding suburban landscape (Table 3). We found out that SRWPs that we monitored differ in accessibility. From this point of view, not only ponds located on a private property have been inaccessible (PP2, PP3, PP4), but so have a pond in the city administration' ground (PM1). On the other hand, we discovered a few accessible ponds located on a private property (PP1, PP5). These cases prove there is a potential for social and ecological bindings in a landscape, if there is a will to support these bindings.

We discovered significant area fluctuations during standard filling and during a dry season when we compared a level area of ponds PM2 and partly also PP5. It is related with a morphometry of ponds, bank inclinations and also with a pond level amplitude. A significant fluctuation of water level occurred in the PM2 pond that we confirmed our own continuous monitoring, makes some stable pond ecosystem and potential vegetation on the banks difficult to create (Fig. 3). Causal precipitation has been measured at the closest meteorological station Pilsen-Mikulka, provided by the Czech meteorological 
institution as a reference station for the territory of the city of Pilsen. Total rainfall for a small new built up area, drained into the pond PM2, have been monitored simultaneously according to other surrounding stations (Stod and University of West Bohemia). After the events have been evaluated, we found out that total rainfalls differed only very little (Fig. 4).

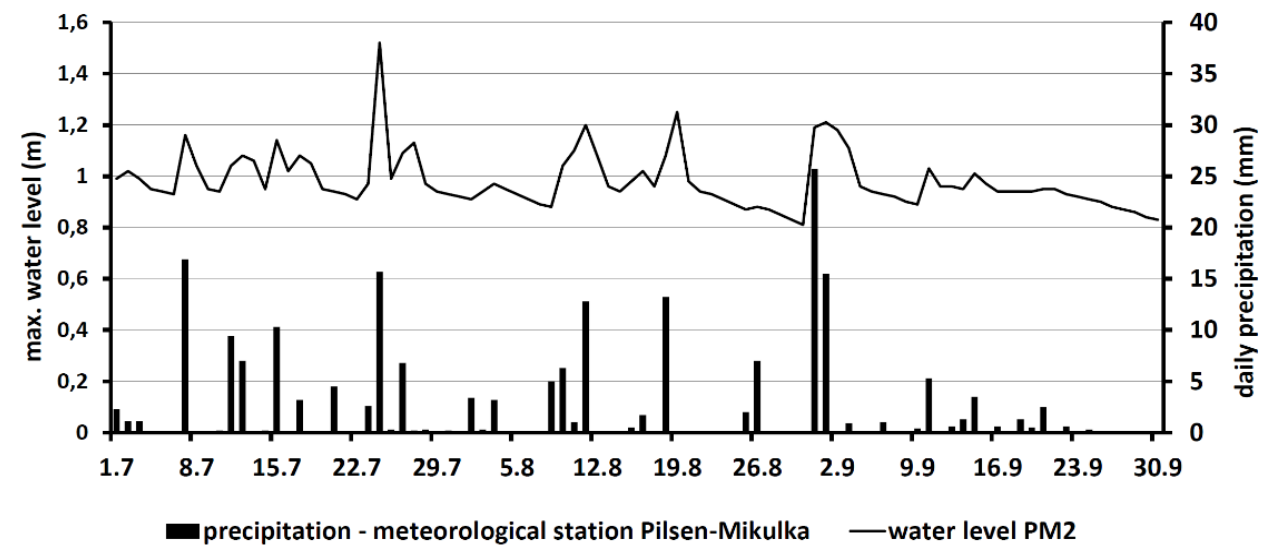

Figure 3. Maximum daily water levels in the retention pond PM2 (Nova Valcha) and daily precipitation in the weather station Pilsen-Mikulka (July-September 2017). Data of water levels: own monitoring; data for precipitation: Czech Hydrometeorological Institute

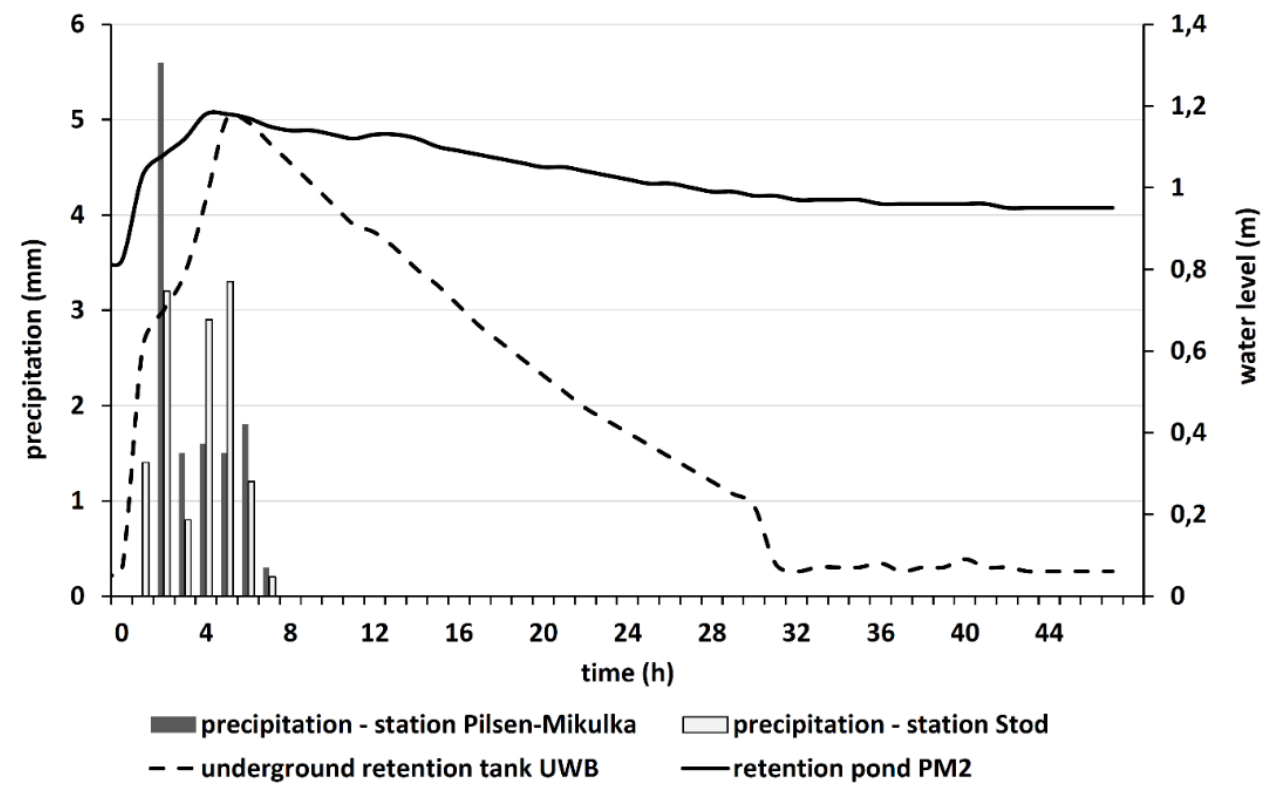

Figure 4. Development of water levels in retention pond PM2 (Nova Valcha) in comparison with underground retention tank $U W B$ with regulated drain in relation with precipitation event (since 22nd October 2017 at 0:00:00 till 24th October 2017 at 0:00:00)

According to project documentation, an assumed depth of the PM2 pond during normal regime should be 1.4-0.9 m. However, the water level oscillated between 1.7$0.53 \mathrm{~m}$ during the monitoring period (Table 4). The lower aggregated average $(0.92 \mathrm{~m})$ reflects an especially significantly dry summer in 2018. Based on an analysis of a few 
precipitation events, an outlet (a drainage coefficient of the area drained into sewerage) shares $40 \%$ out of total rainfall. This figure, however, has to be confirmed with a following monitoring in compliance with a development of neighbouring built-up areas. Our monitoring of water level in the pond PM2 confirmed a huge dispersion of the water level with a negative impact on environmental conditions. As vegetation on the benches does not occur and the pond warms up during low water level, it all creates favourable conditions for algae growth. Follow-up research will have to be focused on monitoring of hydrobiological conditions in SWRPs.

Table 4. Total amplitude of the water level in the pond PM2 (Nova Valcha) between 1st July, 2017-31st December, 2018

\begin{tabular}{c|c}
\hline Minimal water level & $0.53 \mathrm{~m}(23.10 .2018)$ \\
Maximum water level & $1.70 \mathrm{~m}(10.06 .2018)$ \\
Average & $0.92 \mathrm{~m}$ \\
Water level amplitude & $1.17 \mathrm{~m}$ \\
\hline
\end{tabular}

We monitored the water level of the underground retention tank located in the campus of the University of West Bohemia (UWB), which collects water from the roof of one campus building, to compare changes of the water level of the pond PM2 (Nova Valcha). The underground retention tank has a total volume $34.5 \mathrm{~m}^{3}$. Its controlled outflow is according to a request to drain water into common sewerage in a maximum value $41 . \mathrm{s}^{-1} \cdot \mathrm{ha}^{-1}$. At the same time, the regulation is set on the allowed upper speed limit of emptying in order to quickly free up the storage space. These types of tanks are legislatively allowed solutions to drain precipitation water, where infiltration is not possible.

Our monitoring proved that the water level of both retention ponds differ in their reaction rate (Fig. 4). This documented event shows how both retention systems responded on total rainfall $(13 \mathrm{~mm})$, which was recorded during seven night hours on the $22^{\text {nd }}$ September 2017 from surrounding meteorological stations Pilsen-Mikulka and Stod.

The underground retention tank UWB accumulating water from the roof of the building responds faster when filling or emptying. PM2 retention pond on the surface in the residential zone Nova Valcha empties gradually, which is in compliance with its technical function. Surface retention is desirable to limit too fast fluctuation of the water level due to the fact that ecosystem functions of the pond are supported. On the other hand, the underground retention tank has no ecosystem functions.

\section{Discussion}

Based on our SRWPs evaluation, it is possible to specify main adjustments for their successful implementation into the BGI system in suburban landscape. A potential of implementation of SRWPs into BGI is summarized in Table 5.

This potential is influenced not only by parameters of the ponds and their location in the landscape, but also by a functional typology of the territory according to a spatial plan (ÚKRMP, 2016). It is highly recommended that spatial planning endeavors to build up green network in areas focused on production and storage as well as in the areas where sales and services are cumulated (Berlin Konkret). Thus, we can achieve much better 
connectivity of nature-based corridors in a suburban landscape, than it is done when only agriculture and forest lands are interlinked.

Norms and methods prefer surface infiltration over a continuous grassy humus layer. If a drain from hard surface enters into green surfaces with a good infiltration, not a huge retention space is necessary. The case study of the Pilsen-city suburban landscape shows, that wherever a surface has a limited ability to soak up water due to the hydrogeological reasons, private entities can fulfill the rainwater management's duty via SWRPs. Table 5 shows that it is possible to implement SRWPs into BGI, if suitable design principles are applied (Lawrence and Breen, 1998; NJDEP, 2006; Kurilenko and Osmolovskaya, 2007; Blicharska et al., 2016) and relevant implementations into the BGI territorial systems are made, for example in relation to local water bio-corridors.

Table 5. The potential of implementation of surface retention ponds to the BGI

\begin{tabular}{|c|c|c|c|}
\hline $\begin{array}{c}\text { Retention } \\
\text { pond }\end{array}$ & \begin{tabular}{|c|} 
Functional type of the territory \\
according to a spatial plan
\end{tabular} & $\begin{array}{c}\text { Land cover of the surrounding } \\
\text { area }\end{array}$ & Potential of implementation \\
\hline PP1 & industrial and storage areas & lawn and roads & $\begin{array}{l}\text { to connect to the blue-green } \\
\text { infrastructure network }\end{array}$ \\
\hline PP2 & industrial and storage areas & $\begin{array}{l}\text { semi-permeable surfaces and } \\
\text { extensive grass }\end{array}$ & $\begin{array}{l}\text { to make a nature-based ecosystem } \\
\text { of the pond banks }\end{array}$ \\
\hline PP3 & industrial and storage areas & lawn & $\begin{array}{l}\text { to connect into the blue-green } \\
\text { corridor and into a public space }\end{array}$ \\
\hline PP4 & industrial and storage areas & lawn & $\begin{array}{l}\text { to connect into the blue-green } \\
\text { corridor and into a public space }\end{array}$ \\
\hline PP5 & commercial areas & extensive grass & $\begin{array}{l}\text { to make nature-based ecosystem } \\
\text { of the pond banks and to connect } \\
\text { into a public space }\end{array}$ \\
\hline PM1 & natural areas & roads and extensive grass & $\begin{array}{l}\text { to connect into the blue-green } \\
\text { corridor and into a public space }\end{array}$ \\
\hline PM2 & $\begin{array}{l}\text { mixed residential areas - } \\
\text { potentially built-up }\end{array}$ & lawn and roads & $\begin{array}{l}\text { to connect into the blue-green } \\
\text { corridor and into a public space }\end{array}$ \\
\hline MM1 & parks areas & forest park and roads & $\begin{array}{l}\text { to make a nature-based ecosystem } \\
\text { of the pond banks }\end{array}$ \\
\hline
\end{tabular}

There is so far limited knowledge related to ecologic functions of SRWPs, because there is neither systematic monitoring nor an effort to plan their hydrobiological qualities. Foreign experiences could not be automatically applied, unless a home comparative research is realized. Researches made abroad show that ponds could be influenced by inflowing water that contains a specific pollution depending on a characteristic of a drained surface (Stoianov et al., 2000; Scher et al., 2004). For example, a study in northern Poland showed that small ponds located in agricultural landscape have a higher load of nutrients, than those in urban landscape (Jarosiewicz et al., 2018). Urban ponds have been classified in terms of nutrients on the border of meso- and eutrophy (Jarosiewicz et al., 2018). On the other hand, retention ponds could become tools for a pollution decrease. According to British methodologies, ponds significantly decrease a load of dissolved substances or a concentration of non-ferrous metals in water (Woods Ballard et al., 2015). Macrovegetation of littoral zone plays an important role in detoxifying of water in urban ponds (Kurilenko and Osmolovskaya, 2007).

Besides quality of inflowing water, many different criteria have to be considered when a pond is designed (Lawrence and Breen, 1998; NJDEP, 2006; Blicharska et al., 2016). 
Some criteria depends on handling with rainwater (e.g. appropriateness of hydrogeological environment), other ones deal with specifications of their design (e.g. local spatial and slope ratios or implementation into surrounding landscape) or with economic issues, such as operation and maintenance costs in future, ownership, building costs or aspects influencing the economy of water management of the pond itself. There are more specialized methodological publications dealing in detail with selection of measures (WEF, 2014; Woods Ballard et al., 2015; Faltermaier et al., 2016; Perini and Sabbion, 2017).

Ownership relations influence a potential of SRWPs implementation into BGI, especially in terms of legislation for urban and landscape planning as well as the owners" motivation to support nature-based solutions beyond a duty of rainwater retention. There is currently a low motivation in the private sector to voluntarily support BGI in the Czech Republic. It comes out of a lack of political power to pursue new approaches, underestimation and low public awareness about BGI, inappropriately set legislation and a limited scale of opportunities to take over foreign experience from the past (Stránský and Kabelková, 2015; Slach and Ježek, 2015). The situation, however, has been improving in recent years and new methodologies for practical application have been developed (Vítek et al., 2015). A political support for new approaches grows especially in context with a support of adaptation actions of settlements to climate change. Based on an analysis of potential and opportunities in this case study, it is highly recommended to enhance the private sector's motivation to implement SWRPs to BGI.

In the category of normative tools, it is necessary to make BGI one of the requested elements of a landscape. BGI is neither defined nor legislatively anchored in the Czech law yet. BGI could extend current ecological networks (Territorial system of ecological stability) in build-up landscape as a part of planning practice. Ecological networks as part of landscape and regulatory planning are applied predominantly in rural areas, which is not sufficient for suburban areas. The rainwater management obligation (e.g. defining a specific runoff from the land) of municipalities, which legislatively apply for new construction, should be extended by more detailed specification of how they support building of retention elements and nature-based measures. The law about urban planning enables investors to claim a subsidy for infrastructure in the territory. That could be a way to co-finance related BGI elements on public lands.

It is necessary to strengthen economic instruments motivating private sector to apply nature-based measures (Kabisch et al., 2016). Besides decreasing of fees for rainwater drainage, it is possible to take into consideration an ecosystem quality of the measure via e.g. tax land discounts or "green bonuses". The green construction bonuses make regulatory conditions of an investor more favorable, if the investor proves the ecosystem benefits of the measure that has been accomplished (Retzlaff, 2008; Carter and Fowler, 2008; Ferguson et al., 2013).

\section{Conclusion}

The evaluation results of SRWPs in the suburban landscape of Pilsen demonstrated their both positive and negative characteristics, which influence their potential for implementation into BGI. Primary water management functions planned during construction are the same - to control the drain from a residential area during intensive precipitation to temper extremely high discharge waves in rain or common sewerage, or during its drain into a recipient. Parameters of SRWPs are different, especially in terms 
of how their nature-based elements are used or how their amenity functions in a public space are applied. The results based on a few private SRWPs show that their ecological and aesthetic quality could be comparable with those systems built by the city in the public interest and with taking into account their ecosystem functions. It is rarely used a rugged shape of the plan of the ponds when SRWPs are projected. Solidifying of benches with stones should be combined with bench vegetation that can be more beneficial for suburban landscape. The study shows that bench trees and shrub is possible to use around private ponds.

The continuous research should be focused on monitoring of the water quality in SWRPs depending on the season and how the ponds respond to extreme inflows. This is the way how the ponds could be better projected or handled with the pond level. Moreover, our knowledge about the level of fluctuations of SWRPs in compliance with their morphology is insufficient. Missing information about the SWRPs' ecology does not relate only to our case studies region, but to other Czech cities as well. The foreign experience is, however, limited to a few particular studies.

Initial results of the level monitoring of the pond PM2 showed that outflow settings from the pond can significantly influence fluctuations in flooding of its benches as well as other ecological parameters. Still, the surface SWRPs are much more suitable for general improvement of ecological conditions of the landscape than underground SWRPs. Surface SWRPs, besides their ecological, microclimate and aesthetic potentials, play an important role as a part of the BGI network, that can enhance eco hydrological conditions of the suburban landscape, if a proper spatial planning is made. Thus, a city administration must not only register them, but also actively influence their parameters during the construction process of ponds.

Current SWRPs belong objectively between grey- and blue-green infrastructures. This case study shows that it is possible to implement SWRPs located in a suburban landscape into BGI. Water-management practice of the private sector fulfills only obligatory demands for rainwater drain and they have no reason to take into consideration new requirements of society for BGI as a landscape instrument to adapting to climate change. Ecosystem quality of SRWPs differs a lot and is a result of the non-existence of planning and instruments, which could motivate the private sector to carry out nature-based solutions. It is crucial to focus not only normative, but also economic and ethical instruments and pursue a collaboration between private and municipal sectors.

Acknowledgment. This research has been supported by the Technology Agency of the Czech Republic Grant ÉTA TL01000498 "Revitalization of city centers and other public spaces in the Czech Republic: Problems, foreign inspiration, possible solutions".

\section{REFERENCES}

[1] Antrop, M., Eetvelde, V. V. (2000): Holistic aspects of suburban landscapes: visual image interpretation nad landscape metrics. - Landscape and Urban Planning 50: 43-58.

[2] Bacchin, T., Ashley, R., Blecken, G., Viklander, M., Gersonius, B. (2016): Green-blue Infrastructure for Sustainable Cities: Innovative Socio-technical Solutions Bringing Multifunctional value. - In: Novatech 2016, Lyon.

[3] Blicharska, M., Andersson, J., Bergsten, J., Bjelke, U., Hilding-Rydevik, T., Johansson, F. (2016): Effects of management intensity, function and vegetation on the biodiversity in urban ponds. - Urban Forestry \& Urban Greening 20: 103-112. 
[4] Bozovic, R., Maksimovic, C., Mijic, A., Smith, K. M., Suter, I., van Reeuwijk, M. (2017): Blue Green Solutions. A Systems Approach to Sustainable, Resilient and Cost-Efficient Urban Development. - Climate-KIC Limited, Imperial College London, London.

[5] Carter, T., Fowler, L. (2008): Establishing Green Roof Infrastructure Through Environmental Policy Instruments. - Environmental Management 42: 151-164.

[6] Chiandet, A. S., Xenopoulos, M. A. (2011): Landscape controls on seston stoichiometry in urban stormwater management ponds. - Freshwater Biology 56: 519-529.

[7] Cizek, A. R., Hunt, W. F. (2013): Defining predevelopment hydrology to mimic predevelopment water quality in stormwater control measures (SCMs). - Ecological Engineering 57: 40-45.

[8] DELWP (2017): Planning a Green-Blue City. A how-to guide for planning urban greening and enhanced stormwater management in Victoria. - Department of Environment, Land, Water and Planning, Melbourne.

[9] EC (2013): Green infrastructure (GI) - enhancing Europe's Natural Capital, $\operatorname{COM}(2013) 249$. - European Commission, Brussels.

[10] Ehrenfeld, J. G. (2000): Evaluating wetlands within an urban context. - Ecological Engineering 15: 253-265.

[11] Elemer, V., Fraker, H. (2012): Water, neighborhoods nad urban design: micro-utilites and the fifth infrastructure. - In: Howe, C., Mitchell, C. (eds.) Water Sensitive Cities. IWA Publishing, London.

[12] Faltermaier, M., Stock, H., Tonndorf, T. (2016): Stadtentwicklungsplan Klima KONKRET Klimaanpassung in der Wachsenden Stadt. - Senatsverwaltung für Stadtentwicklung und Umwelt, Berlin.

[13] Ferguson, B. C., Fratzeskaki, N., Brown, R. (2013): A strategic program for transitioning to a Water Sensitive City. - Landscape and Urban Planning 117: 32-45.

[14] Freie und Hansestadt Hamburg (2013): Mehr Stadt in der Stadt. Gemeinsam zu mehr Freiraumqualität in Hamburg. - Freie und Hansestadt Hamburg, Behörde für Stadtentwicklung und Umwelt, Hamburg.

[15] Harman, B. P., Taylor, B. M., Lane, M. B. (2015): Urban partnerships and climate adaptation: challenges and opportunities. - Current Opinion in Environmental Sustainability 12: 74-79.

[16] Hassall, Ch. (2014): The ecology and biodiversity of urban ponds. - WIREs Water 1: 187206.

[17] Hayllar, M. R. (2010): Public-Private Partnerships in Hong Kong: Good Governance - The Essential Missing Ingredient? - The Australian Journal of Public Administration 69(S1): S99-S119.

[18] Hill, M. J., Biggs, J., Thornhill, I., Briers, R. A., Gledhill, D. G., White, J. C., Wood, P. J., Hassall, C. (2017): Urban ponds as an aquatic biodiversity resource in modified landscapes. - Glob Change Biol 23: 986-999.

[19] Hoang, L., Fenner, R. A. (2016): System interactions of stormwater management using sustainable urban drainage systems and green infrastructure. - Urban Water Journal 13(7): 739-758.

[20] Jarosiewicz, A., Radawiec, B., Hetmański, T. (2018): Effect of Catchment Land Use on Trophic State Variables of Small Water Bodies (Northern Poland). - Water Resources 45: 615-623.

[21] Kabisch, N., Frantzeskaki, N., Pauleit, S., Naumann, S., Davis, M., Artmann, M., Haase, D., Knapp, S., Korn, H., Stadler, J., Zaunberger, K., Bonn, A. (2016): Nature-based solutions to climate change mitigation and adaptation in urban areas: perspectives on indicators, knowledge gaps, barriers, and opportunities for action. - Ecology and Society 21(2): 39.

[22] Kopp, J., Frajer, J., Pavelková, R. (2015): Driving forces of the development of suburban landscape - a case study of the Sulkov location west of Pilsen. - Quaestiones Geographicae 34: 51-64. 
[23] Kopp, J., Raška, P., Vysoudil, M., Ježek, J., Dolejš, M., Veith, T., Frajer, J., Novotná, M., Hašová, E. (2017): Ekohydrologický management mikrostruktur městské krajiny (Ecohydrological management of the urban landscape's microstructures). - University of West Bohemia, Pilsen.

[24] Koppenjan, J. F. M. (2015): Public-Private Partnerships for green infrastructures. Tensions and challenges. - Current Opinion in Environmental Sustainability 12: 30-34.

[25] Koronkevich, N. I., Mel'nik, K. S. (2015): Runoff Transformation under the Effect of Landscape Changes in the Moskva R. Basin and in the Territory of Moscow City. - Water Resources 42: 159-168.

[26] Krauze, K., Wagner, I. (2019): From classical water-ecosystem theories to nature-based solutions - Contextualizing nature-based solutions for sustainable city. - Science of the Total Environment 655: 697-706.

[27] Kurilenko, V. V., Osmolovskaya, N. G. (2007): Bioindication Role of Higher Plants in the Diagnostics of Aquatic Ecosystems: Case Study of Small Water Bodies in St. Petersburg. - Water Resources 34: 718-724.

[28] Lawrence, I., Breen, P. (1998): Design Guidelines: Stormwater Pollution Control Ponds and Wetlands. - Cooperative Research Centre for Freshwater Ecology, Canberra.

[29] Le Viol, I., Mocq, J., Julliard, R., Kerbiriou, Ch. (2009): The contribution of motorway stormwater retention ponds to the biodiversity of aquatic macroinvertebrates. - Biological Conservation 142: 3163-3171.

[30] Li, Z., Xie, C., Lu, H., Che, S. (2019): The rational planning of public open space exploring the effects of environmental factors on human recreation - a case study in Shanghai, China. - Applied Ecology and Environmental Research 17(1): 1247-1260.

[31] Linton, J., Budds, J. (2014): The hydrosocial cycle: Defining and mobilizing a relationaldialectical approach to water. - Geoforum 57: 170-180.

[32] Margerum, R. D., Robinson, C. J. (2015): Collaborative partnerships and the challenges for sustainable water management. - Current Opinion in Environmental Sustainability 12: 53-58.

[33] McAllister, R. RJ., Taylor, B. M. (2015): Partnerships for sustainability governance: a synthesis of key themes. - Current Opinion in Environmental Sustainability 12: 86-90.

[34] Miller, J. D., Hess, T. (2017): Urbanisation impacts on storm runoff along a rural-urban gradient. - Journal of Hydrology 552: 474-489.

[35] Moore, T. L. C., Hunt, W. F. (2012): Ecosystem service provision by stormwater wetlands and ponds - a means for evaluation? - Water Research 46(20): 6811-6823.

[36] NJDEP (2006): New Jersey Stormwater Best Management Practices Manual. - Department of Environmental Protection, New Jersey.

[37] Noble, A., Hassall, Ch. (2015): Poor ecological quality of urban ponds in northern England: causes and consequences. - Urban Ecosystems 18(2): 649-662.

[38] Perini, K., Sabbion, P. (2017): Urban Sustainability and River Restoration. Green and Blue Infrastructure. - WILEY Blackwell, Chichester.

[39] Pizarro, R. E. (2015): Challenges of implementing sustainable urban design plans through community - university partnerships: lessons from Colombia, China, and Germany. Current Opinion in Environmental Sustainability 17: 48-56.

[40] Povodí Vltavy (2018): Možnost eliminace vzniku kyslíkových deficitů v toku Berounky pod Plzní (Possibility of elimination of oxygen deficits in the Berounka river under the Pilsen). - Povodí Vltavy, State Enterprise, Pilsen.

[41] Retzlaff, R. C. (2008): Green Building Assessment Systems: A Framework and Comparison for Planners. - Journal of the American Planning Association 74(4): 505-519.

[42] Rygaard, M., Binning, P. J., Albrechtsen, H.-J. (2011): Increasing urban water selfsufficiency: New era, new challenges. - Journal of Environmental Management 92: 185194.

[43] Scher, O., Chavaren, P., Despreaux, M., Thiéry, A. (2004): Highway stormwater detention ponds as biodiversity islands? - Arch.Sci. 57: 121-130. 
[44] Schmidt, M. (2009): Rainwater Harvesting for Mitigating Local and Global Warming. In: Cities and Climate Change: Responding to an Urgent Agenda. Fifth Urban Research Symposium, Marseille.

[45] Slach, O., Ježek, J. (2015): Czechia. - disP - The Planning Review 51(1): 28-29.

[46] Spilková, J., Šefrna, L. (2010): Uncoordinated new retail development and its impact on land use and soils: A pilot study on the urban fringe of Prague, Czech Republic. Landscape and Urban Planning 94: 141-148.

[47] Stoianov, I., Chapra, S., Maksimovic, C. (2000): A framework linking urban park land use with pond water quality. - Urban Water 2(1): 47-62.

[48] Stránský, D., Kabelková, I. (2015): Review of the Implementation Process of Sustainable Stormwater Management in the Czech Republic. - In: Hlavínek, P., Zeleňáková, M. (eds.) Storm Water Management. Examples from Czech Republic, Slovakia and Poland. Cham. Springer, Heidelberg, New York, Dordrecht, London.

[49] Swyngedouw, E. (2009): The Political Economy and Political Ecology of the Hydro-Social Cycle. - Journal of Contemporary Water Research \& Education 142: 56-60.

[50] Teurlincx, S., Kuiper, J. J., Hoevenaar, E. C., Lurling, M., Brederveld, R. J., Veraart, A. J., Janssen, A. B., Mooij, W. M., de Senerpont Domis, L. N. (2019): Towards restoring urban waters: understanding the main pressures. - Current Opinion in Environmental Sustainability 36: 49-58.

[51] ÚKRMP (2016): Územní plán Plzeň (Master Plan of the City of Pilsen). - The City of Pilsen Urban Planning Institute, Pilsen.

[52] USEPA (2009): Stormwater wet pond and wetland management guidebook. - United States Environmental Protection Agency, Center for Watershed Protection Protection Agency, Ellicott City.

[53] Van Timmeren, A., Kuzniecow Bacchin, T., Aires, C. (2015): Green Blue Infrastructures: Overview of Smart Spatial Strategies: implications for future innovation in design processes. - Delft University of Technology, Delft.

[54] Vítek, J., Stránský, D., Kabelková, I., Bareš, V., Vítek, R. (2015): Hospodaření s deštovou vodou v ČR (Rainwater management in the Czech Republic). - ZO ČSOP Koniklec, Prague.

[55] Voskamp, I. M., Van de Ven, F. H. M. (2015): Planning support system for climate adaptation: composing effective sets of blue-green measures to reduce urban vulnerability to extreme weather events. - Build. Environ. 83: 159-167.

[56] Wagner, I., Krauze, K., Zalewski, M. (2013): Blue aspects of green infrastructure. Sustainable Development Applications 4: 145-155.

[57] WEF (2014): Green infrastructure implementation. - Water Environment Federation, Alexandria.

[58] Wong, T. H. F. (2013): Blueprint 2013. Stormwater Management in a Water Sensitive City. - Cooperative Research Centre for Water Sensitive Cities, Clayton.

[59] Wong, T., Breen, P., Somes, N. L. G., Sara, D. L. (1998): Managing Urban Stormwater Using Constructed Wetlands. - Cooperative Research Centre for Catchment Hydrology, Clayton.

[60] Woods Ballard, B., Wilson, S., Udale-Clarke, H., Illman, S., Scott, T., Ashley, R., Kellagher, R. (2015): The SUDS manual (C753). - CIRIA, London.

[61] Yang, J.-Y., Zhang, B., Wu, Y.-F., Feng, Y.-R., Zheng, Y., Shi, B.-X. (2019): Balance between construction and conservation: strategy in water sensitive area planning. - Applied Ecology and Environmental Research 17(4): 7283-7299. 